\title{
3 \\ The Ideological Contest: Election 2016
}

\author{
Carol Johnson
}

Analysing the ideological components of election campaigns can provide key insights into the arguments that parties use to try to influence voters and the differences in their policy positions. ${ }^{1}$ This is particularly so in the case of the 2016 election campaign, which arguably saw a more explicit and substantial ideological divide than many recent elections. However, as usual, the term ideology was only used pejoratively to criticise opponents' incorrect views, rather than being something that parties positively claimed for themselves. This chapter outlines the key features of this ideological contest, limiting its analysis to the two major parties: Labor and Liberal. The two major parties' ideological differences are focused on because their ideological contest is the one that is most crucial for influencing the formation of government. Furthermore, it would not be feasible to cover the ideology of all the minor parties contesting the 2016 election in one chapter, even the most significant ones such as the Nationals, the Greens, Pauline Hanson's One Nation and the Nick Xenophon Team. Nonetheless, the major parties' efforts to position themselves ideologically in regard to the minor parties will be examined. The major parties' ideological differences will be explored through the prisms of the parties'

1 The concept of ideology is used here to refer to broad, umbrella-like frameworks of belief that can include differing strands (see further Johnson 2007: 15-20). 
economic and social policies. The chapter will conclude by identifying some of the potential problems that the ideological contest posed for both major parties.

\section{Labor and economic policy}

Several months before the election was announced, Bill Shorten argued that Labor was quite explicitly engaging in a battle of ideas with the Coalition government (Shorten 2016b). Labor had been undertaking substantial policy work with that in mind. Indeed, policy differences soon became apparent as Shorten proudly stated that Labor had moved away from using a small-target election strategy (whereas, in recent election campaigns, Labor had often avoided stating controversial positions on social and economic issues) (Shorten 2016k; see also Marr 2016: 174). In particular, Labor positioned Malcolm Turnbull and the Coalition as supporting the big end of town and argued that the Coalition's proposed tax cuts to business, their opposition to Labor's attempts to restrict negative gearing, their budget cutbacks and their opposition to a Royal Commission into the banking sector were all evidence of this. Turnbull was depicted as elitist and out of touch with ordinary voters (Shorten 2016f).

By contrast, Labor depicted itself as supporting the interests of the middle and working classes against the Coalition's support for big business. It is ideologically significant that the word 'class' was quite explicitly mentioned in Labor's campaign material, given that it had tended not to be mentioned in recent years. ${ }^{2}$ Even the Labor and union campaign against John Howard's WorkChoices in the 2007 election had tended to use the term 'working families' as code for class. In line with that narrative, Shorten attempted to throw off his image as a ruthless, factional powerbroker (Marr 2016). He was depicted as a caring and empathetic person who believed government should ensure good-quality healthcare and education, the creation of jobs, good pay and working conditions, along with a strong welfare safety net (Shorten 2016f). ${ }^{3}$

2 For example, the Labor website proudly proclaimed that: 'A Shorten Labor Government will stand up for middle and working class families across Australia' (see Australian Labor Party (ALP) n.d.-a).

3 Polling suggested that Shorten was indeed seen as more caring and empathetic than Turnbull, though Turnbull was seen as a more capable economic manager (Hudson 2016). 
Labor argued that Australian society had been characterised by a growing economic inequality that Coalition policies had fostered and that the election of a Turnbull government would worsen this situation (Shorten 2016c). Indeed, issues of 'inequality' featured far more prominently and explicitly in this election campaign than in other recent Labor ones. Labor argued that such inequality was not only unjust, but also bad for the economy since:

the best way to have sustainable economic growth in Australia is to have fair distribution of income. We've got to ensure that we have inclusive growth. Inequality—and it's at a 75-year high-is a handbrake on economic growth (Shorten 2016d).

Labor produced a 138-page report, 'Growing Together', which quoted the International Monetary Fund (IMF), the Organisation for Economic Co-operation and Development (OECD) and Nobel prize-winning economist Joseph Stiglitz to back up Labor's case that increasing inequality dampens economic growth, including via low incomes reducing people's ability to consume (ALP n.d.-c). Shorten also argued that funding an excellent education system that produced highly skilled employees was essential for Australia's economic growth and that properly funding Medicare was not just a social justice and equal opportunity measure, but also improved employees' health and their ability to participate in the labour force (Shorten 2016c).

By contrast, voters faced the 'same old Liberals; just give tax cuts to the top end of town and let the rest of the people just make do with not much at all' (Shorten 2016h). Labor's so-called 'Mediscare' campaign-in which Labor claimed that the Coalition was intent on privatising Medicare (rather than just undermining it by increasing the user-pays component)reinforced the Labor narrative, even though the accuracy of such claims was questioned by many commentators (ALP 2016; Shorten 2016m; for Turnbull's denials see Turnbull 2016k). Shadow Treasurer Chris Bowen also outlined what he saw as the major (ideological) policy differences between Labor and the Liberals when it came to budget measures.

The differing approaches to fiscal repair between the two major parties this election could not be more stark. The Liberals' Reagan-esque approach of delivering tax cuts for big business and hoping it will trickle down through the economy will blow an ever increasing hole in the Budget bottom-line. Labor will undertake responsible reforms in areas such as negative gearing and capital gains tax and will close tax loopholes to deliver ever increasing improvements to the Budget bottom-line (Bowen 2016a). 
Labor also argued that the Turnbull government had gone too far in its support for free trade. While supporting free trade agreements, Labor stated its support for 'proper social democratic institutions and progressive policies'. Consequently, trade agreements needed to maximise the employment of Australians and avoid undermining 'public policy in healthcare, the environment or labour rights' (Wong 2015). Labor would not accept Investor-State Dispute Settlement (ISDS) provisions in new trade agreements and would attempt to remove or mitigate such provisions in existing free trade agreements already negotiated by Coalition governments (Wong 2016a). Meanwhile, Shorten endorsed a 'Made in Australia' campaign, claiming:

there's a lot of blue-collar working-class and middle-class families who are sick of seeing all of our jobs being exported overseas, who are greatly sceptical that there aren't rorts in some aspects of our visa system (Shorten 2016o).

Shorten was aware that dissatisfaction with globalisation and neoliberalism were reshaping politics internationally, as reflected in some voters' support for Donald Trump in the United States (US) and Brexit in Britain. He argued that Labor's plans for 'inclusive growth', good health and welfare systems along with good pay and working conditions (including penalty rates) were the best way of ensuring that voters' needs were met and that they did not resort to extreme protest votes. By contrast, Turnbull's policies, including his 'tax policies for the elites', would result in an economically 'divided society' and reflected the type of politics that many voters were rejecting internationally (Shorten 20160).

So Labor was implying that Turnbull was influenced by a right-wing ideological belief in austerity-style cuts to the public sector, 'trickledown' economics and a reduction of necessary regulation in free trade agreements that would have dire consequences for ordinary Australians. In many respects, Labor seemed to be consolidating a move away from the neoliberal ideology that had influenced it under the Hawke and Keating governments and had begun to be questioned from the Rudd period on, despite some continuing flirtations with market-influenced policies (Johnson 2011).

However, Labor was hesitant to acknowledge any differences with the iconic Hawke and Keating governments, even using Bob Hawke as a figurehead in campaign advertising. Bowen answered critics who accused Labor of moving away from Paul Keating's support for tax cuts 
by pointing out that Keating would not have supported an unfunded cut to corporate tax, and had only supported such cuts as part of a tax package that increased revenue from other sources (Bowen 2016b). He also claimed that neither he nor Shorten 'oppose corporate tax relief as a matter of ideology, but as a matter of hard-nosed prioritisation' (ibid.). A concern with eventual fiscal balancing in the longer term indeed led to some hard Labor decisions (such as only reinstituting $\$ 2$ billion of the Coalition's proposed $\$ 57$ billion cut to hospitals in the 2014 Budget, or reducing family tax benefit for families earning over $\$ 100,000$ ) (Shorten 2016o; Shorten, Bowen and Burke 2016). As Shorten put it: '[O]ver the next four and 10 years we start the action to fundamentally reduce the level of government debt in this country. We will need to make difficult decisions as this election unfolds' (Shorten, Bowen and Burke 2016). Labor pledged that while deficits would be bigger in the first few years than those projected by the Coalition, budgets would be brought back into surplus by the same year as the Coalition pledged-2021 (ibid.). Bowen suggested it was ridiculous that Labor was accused of being antibusiness by the Coalition, just because they were suggesting that business continue to pay the existing tax rate.

If you believe the rhetoric of the government, you would be forgiven for thinking our policy is reminiscent of Che Guevara. In fact, we are simply arguing that the budget can't afford at this time to change the tax rate Peter Costello introduced (Bowen 2016b).

Nonetheless, there was more than just a shift in populist rhetoric particularly targeting Turnbull's links with business and the big end of town. It was noticeable that Labor was making far fewer statements explicitly mentioning the positive role of private enterprise and markets in the economy, compared not just with Hawke and Keating but also with Kevin Rudd and Julia Gillard (Johnson 2011: 562-79). It was as though, after deciding to reject key elements of their 30-year engagement with neoliberalism, Labor had forgotten how it had nuanced its message to the electorate prior to then. Claims Labor is antibusiness can scare electors by suggesting that Labor will not be able to manage an economy in which the private sector plays such a crucial role, including as employers of many voters. Traditionally, Labor has tended to argue that its policies were fortuitously in the interests of both labour and socially beneficial sections of private enterprise; that there is a harmony of interests between 
the two (Johnson 1989). ${ }^{4}$ For example, even when Ben Chifley advocated nationalising the banks, he argued that he was doing so not only because their financial practices harmed workers, but because the banks had failed to give essential credit to small business in times of economic downturn and had also failed to fund the development of Australian manufacturing industry because of their links with competing overseas capital (Johnson 1986: 48-49). In the 2016 election campaign, Labor did emphasise that its policies were good for economic growth, but rarely explicitly spelled out that this meant they were also good for business.

\section{Labor and social issues}

Labor's rejection of the small-target strategy did not just cover economic issues. It also extended to many social issues (though Labor continued to support turning back asylum-seeker boats, and the offshore processing of asylum seekers). Shorten strongly supported Indigenous equality and reconciliation, implying that he might support a Treaty, and denounced 'systemic racism' (Shorten 2016g, 2016k). Shorten strongly supported equal rights for women-in political representation, in countering domestic violence, in terms of encouraging women into new information technology careers and in terms of equal pay (Shorten 2016i, 2016j, 2016k; ALP n.d.-b). He had 'always been a feminist' (Shorten, Bowen and Burke 2016).

Shorten began a major appearance in the western Sydney suburb of Penrith with a statement of empathy, not only for the victims of the US Orlando massacre and their families, but also for the pain that members of the Australian lesbian, gay, bisexual, trans and intersex (LGBTI) community would be feeling (Shorten 2016k). ${ }^{5}$ Labor supported marriage equality (albeit formally retaining a conscience vote until around 2019) arguing:

at its heart, marriage equality is about removing discrimination from our laws. It is a recognition that love between two people of the same gender is of equal meaning, equal value and entitled to equal respect (ALP n.d.-d).

\footnotetext{
4 Yet Shorten articulated clear social harmony arguments in his own book (as well as having a reputation as a union official who sometimes negotiated deals that were too conciliatory towards business) (see Shorten 2016a: 4-5, 26).

5 Indeed, after the Orlando shootings, a number of LGBTI leaders argued that Turnbull should drop the idea of a plebiscite (Power 2016).
} 
By contrast, Labor stated that 'Malcolm Turnbull's plebiscite will give a taxpayer-funded platform and a megaphone to the very worst forms of hateful abuse' (ibid). Labor also pledged to support the 'Safe schools' antihomophobic bullying program from being cut when the Turnbull government would cease funding (ALP n.d.-e). Earlier Shorten had stated:

So when it comes to the welfare of our children, if I have to choose between: the teachers, the principals and the school counsellors of Australia, or the rabid ideologues of the Liberal-National parties - I will choose Australian teachers and schools any day. Mr Turnbull has a very simple choice here. Stand with the great majority of Australians or a small right-wing fringe. Today we will see how scared he is of his Liberal party (Shorten 2016e).

Consequently, Labor's increased emphasis on an equality agenda not only reflected changing Labor values, it was being used to suggest that the Liberals were deepening inequality. More specifically, it was being used to target Turnbull's ideological position in another way, by suggesting that Turnbull had backtracked on his own moderate, small 'l' liberal beliefs by giving in to conservative forces in his own party on issues ranging from climate change and the republic to same-sex marriage (Shorten 2016h).

In other words, Labor was suggesting that Turnbull was simultaneously dangerously ideological in his support for big business and 'trickle-down' economics while being untrue to his own ideological position on socially progressive issues. Shorten questioned Turnbull's masculinity, suggesting that he was 'a weak man beholden to the right wing of his party' (Shorten 2016o). Anthony Albanese, a senior minister from the Labor Left, argued that voters were disappointed in Turnbull because 'when they look at Malcolm Turnbull, they hear Tony Abbott' (Albanese 2016).

\section{The Liberals and economic policy}

Turnbull came to office portraying a positive message of hope and claiming that 'there has never been a more exciting time to be an Australian' (Turnbull and Bishop 2015). His government would have a plan to ensure that Australia could meet the economic and technological challenges ahead, but one that would be based on being 'a thoroughly Liberal Government committed to freedom, the individual and the market' - in other words, committed to the traditional tenets of Liberal ideology (ibid.). These themes were to underlie much of the subsequent election campaign. 
However, by the time of the election, Turnbull was increasingly aware that some people were feeling concerned rather than excited 'about the security of their job, the prospects for their business, the security for their children's jobs' (Turnbull 2016e). There were leaks from within the Coalition (Mayer 2016) that internal polling revealed many voters were nervous about Turnbull's claims that Australians were living in 'exciting times' and preferred Howard's aim of making voters 'relaxed and comfortable'. Some conservative MPs claimed that, while it might play well in inner-city seats such as the Prime Minister's own Sydney electorate of Wentworth, it did not go down well in suburban or regional seats. In the words of one MP:

nobody knows what it is about. If they do know, they are scared of it. They don't want to live in exciting times. If you are a truck driver or bank teller, it might cost you your job (cited in Mayer 2016).

Consequently, Turnbull finessed this message, arguing that they were exciting but also challenging and uncertain times that required good economic management (Turnbull 2016g). He acknowledged that 'hardworking Australians are seeing this reality on the nightly news-how trade, globalization, and, above all, technological change is producing both new opportunities and also uncertainty in their world' given an 'intensely competitive and volatile' global economy (Turnbull 2016f). He pledged that the government's economic plan would 'deliver stronger economic growth and more jobs and better jobs and take advantage of the great opportunities in the current economic environment' (Turnbull 2016e).

Turnbull argued that Australians were faced with 'two very different versions of what Australia should look like in the future' (Turnbull 2016f). The Coalition's economic plan would make Australia a successful, innovative, twenty-first-century economy in which 'we can secure our future as a high-wage first world economy with a generous social safety net' (ibid.). By contrast, Labor seemed to assume that economic growth would continue however much they taxed or spent (ibid.). Shorten was 'setting up an anti-business, high-taxing high-spending, big borrowing program that will put our economy backwards. It will put our economy into reverse. It will put the jobs of every Australian at risk' (Turnbull 2016g). Labor was engaging in 'class war' and 'the politics of envy' (Turnbull 2016b). In short, while Turnbull denied that he himself was ideological, he accused Shorten of running 'an incredibly ideological war against business' and therefore against the interests of economic growth 
and everyone employed in the private sector (Turnbull 2016e, 2016r). ${ }^{6}$ Turnbull's support for greater restraint on government spending and tax cuts for business was quite consistent with his previous positions, including his arguments against what he saw as the excessive Labor spending in the Rudd government's stimulus package during the global financial crisis (GFC), and that government's failure to institute tax cuts instead (Turnbull 2009).

However, Turnbull attempted to counter Labor scare campaigns about public sector cuts by stating that the government would never privatise Medicare.

Medicare is a core government service. It will always be delivered by the government and every element of Medicare's activities will continue to be delivered by the government ... Now what Mr Shorten is doing ... is running is a disgraceful scare campaign (Turnbull, Joyce and Nash 2016).

Turnbull also made an effort to depict himself as more caring and empathetic, arguing for example that, if re-elected, his government 'will invest \$15 million to ensure older Australians feel safe, cared for, and respected' (Turnbull 2016i). Despite calling the election on two policies designed to curb union power (a position that Turnbull also claimed was not ideological), Turnbull gave an undertaking that 'we will not make any changes to penalty rates. It is a matter for the independent umpire, the Fair Work Commission', but ruled out the government making a submission, as Shorten had pledged to do, in support of penalty rates (Turnbull 2016j, 2016q).

The government did not always provide a great deal of detail regarding their economic plans, other than support for measures such as tax cuts. Turnbull had an ideological dilemma. He wanted to develop an agile, innovative, twenty-first-century economy. However, given his neoliberalinfluenced views, he also believed in there being limits on how much government should intervene in the economy, despite occasional forays to shore up shipbuilding or the steel industry in electorally at-risk seats (Turnbull 2016m, 2016p). In such situations, talking up innovation and opportunities is actually seen as one of the important ways in which government can change the culture. Rhetoric about changing the culture to make it more entrepreneurial and friendly to innovation is seen as itself contributing to an increase in business confidence.

6 Turnbull regularly claims not to be ideological (see Crabb 2016: 175-78). 


\section{The Liberals and social issues}

In an interview with Peter Hartcher (2016), Turnbull strongly denied Labor claims that he was rejecting his own previous ideological positions on progressive social issues. He pointed out that he still supported a republic and that the issue should be revisited when the Queen's reign ends. On climate change, Turnbull argued that 'Australia would meet its emissions reduction targets by 2020 , and could strengthen policies if necessary to meet 2030 targets' (Hartcher 2016). Turnbull restated his support for same-sex marriage. However, he noted that he had inherited a plebiscite and, despite having previously argued against one, it would be too hard to remove the possibility of a popular vote now (ibid.).

Turnbull might have been hamstrung by socially conservative forces in his party in terms of supporting a plebiscite on same-sex marriage. However, the tone of the statements he made during the election campaign was very different from that of his immediate Liberal prime ministerial predecessors, particularly Howard, especially when it came to 'Culture Wars' issues, in which socially conservative values had been mobilised against more 'progressive' views on issues such as race, gender and sexuality. Turnbull proudly proclaimed that 'I would describe myself as a feminist' and supported encouraging women into STEM (Science, Technology, Engineering and Mathematics) areas (Turnbull 2016d). He also strongly supported policies for Indigenous entrepreneurship and reconciliation (Turnbull 2016c). Furthermore, rather than mobilising Howard-style arguments about 'black armband' views, Turnbull argued that we needed to be prepared 'to look into the darkest corners' of our history (ibid.).

The difference with both Howard and Abbott was particularly clear in the wake of the Orlando massacre in the US. A few days after this event, Turnbull hosted an Iftar dinner, ending the Ramadan fast. Unlike Howard or Abbott, there was no emphasis on the Anglo-Celtic heart at the core of Australian identity. Rather, Turnbull used the occasion to state that 'we are the most successful and harmonious multicultural society in the world. Our multicultural success is at the heart of our national identity. It is intrinsic to our history and our character' (Turnbull 2016h). While denouncing the perversions of Islam used by terrorists, Turnbull stated that 'by breaking bread, by sharing food across religions and by bringing diverse people of diverse backgrounds together, we embody Islam's emphasis on the diversity of humanity' (ibid.). He praised the contributions that Muslims had made to Australian society from the days 
of the "Makassan fishermen who traded with our first Australians in the 1600 s, to the Afghan camel drivers who opened up the interior of our vast continent' and continued with the contributions that Muslims of every profession and calling continue to make to Australia (ibid.). He assured Australian Muslims:

that the Australian Muslim community is valued and respected - and it is not confined to a narrow security prism - you are an integral part of an Australian family that rests on the essential foundation of mutual respect and understanding. Every one of us is enriched by the culture and the faiths of our friends and neighbours (ibid.).

He subsequently stated that he would not have invited a sheikh who had homophobic views if he had known, because 'I will always condemn any remarks which disrespect any part of our community, whether it is on the basis of their sexuality, their gender, their race, their religion' (Turnbull, Joyce and Nash 2016). Nonetheless, while he avoided 'Culture War'style arguments on other issues, Turnbull endorsed the effectiveness of both Howard's and Abbott's polices on stopping asylum-seeker boats. $\mathrm{He}$ argued, '[W]e have once again restored the security of our borders. The security which Labor abandoned' (Turnbull 2016r).

Insofar as there were 'Culture Wars'-style comments highlighted in the campaign, they tended to be made by Liberal politicians other than Turnbull. A key example, in regard to heteronormative ideology and samesex marriage, was exemplified in an exchange of views between Penny Wong and Scott Morrison. Wong had argued that heterosexual politicians who supported a plebiscite did not adequately appreciate or acknowledge that encountering hate speech was part of gays' and lesbians' everyday life. The plebiscite would therefore undoubtedly unleash homophobia that would be very hurtful to many gays and lesbians and their families (Wong 2016b). Morrison responded by saying that he did understand Wong's concern because:

I know it from personal experience, having been exposed to that sort of hatred and bigotry for the views I've taken ... Frankly people of very strong religious views have been subject to quite dreadful hate speech and bigotry (cited in Dziedzic and Norman 2016).

However, Wong argued that Morrison's situation was fundamentally different because while all politicians 'receive pretty robust' emails, gays and lesbians are 'targeted in their schools and in their workplaces as well as in public. They're not targeted because of their beliefs or the things 
that they say. They are targeted because of who they are' (Wong 2016c). Furthermore, in her original comments, Wong had pointed out that there was not only a long history of male homosexuality being illegal, and of legal discrimination against gays and lesbians when it came to citizens' rights and entitlements, but that many gays and lesbians were still fearful of the consequences of even holding hands in public (Wong 2016b). Consequently:

it would be good if people had some empathy and compassion for the experience of LGBTI Australians, gay and lesbian Australians, young people in our schools who are still at greater risk of suicide because of the prejudice and discrimination they experience (Wong 2016c).

The exchange between Wong and Morrison is particularly relevant to the analysis of ideology in this chapter because it harked back to Howard-era 'Culture War' arguments that it was actually 'mainstream' Australians who were being predominantly discriminated against by 'politically correct' views about minority rights (Johnson 2007: 39-72). Empathy was to be reserved for the put-upon 'mainstream', rather than minority groups. So Morrison's argument was an important signal to socially conservative voters that such perspectives were still present amongst government MPs, despite Prime Minister Turnbull's own more small 'l' liberal beliefs.

Turnbull himself largely avoided discussing such issues. He simply asserted his belief that the plebiscite would pass (thereby revealing an underlying assumption that numbers in the new Senate would not allow a plebiscite to be blocked) and that legislation in support of same-sex marriage would then 'sail through the Parliament' (Turnbull 2016o). ${ }^{7}$ There were also other signs that Turnbull was reluctant to engage in 'Culture War' arguments to shore up socially conservative ideology. For example, Turnbull alerted socially conservative MPs, and 'Culture War' warriors, such as George Christensen and Cory Bernardi, to the need to be cautious about the language used when discussing issues such as the Safe Schools program and same-sex marriage (Turnbull 2016a, 2016n; though on the latter see Bernardi's denial in Lewis 2016).

The Coalition has run scare campaigns in many previous elections suggesting that a Labor government would be bad for the economy. In respect to economic policy, the ideological position of the Turnbull

7 This assumption would ultimately prove incorrect. In November 2016, the Senate defeated the proposed plebiscite 33 votes to 29 . 
government going into the election was very similar to that of previous Liberal positions. However, despite arguments that Turnbull had sold out to the social conservatives of his party on key issues, it was noticeable that Turnbull avoided mobilising 'Culture War' fears, although he did play the 'border security' card. By contrast, Howard had aimed to develop an electoral coalition of socially conservative 'mainstream' Australians, which also targeted Labor-voting economic 'battlers' who were concerned about social change. Indeed, Howard had attempted to reconcile voters to rapid economic change by suggesting that social change could be held back (Johnson 2007: 39-72). It was a mantle that Abbott, and other social conservatives in the Liberal Party, had largely inherited. Turnbull's vision of a Liberal voter's identity seemed to be more diffuse and less clearly articulated. Turnbull made traditional Liberal appeals to those concerned about sound economic management, free markets, economic growth and jobs. However, the 'exciting' future he was selling also highlighted a focus on innovation that may have been more attractive to entrepreneurial sections of the business community than to some ordinary voters. His focus on social diversity pleased moderate Liberal voters and could have crossover appeal to some Labor and Greens voters. However, it also risked alienating some former Liberal voters who had supported Howard's and Abbott's social conservatism.

\section{Major parties-differentiating themselves from the minor parties}

Key minor parties are analysed in more depth in the chapters by Gregg Cockfield and Jennifer Curtin, Glenn Kefford and Stewart Jackson in this volume. However, both major parties drew on their key ideological positions to distance themselves from minor parties and Independents and to implicate their opponents in what they depicted as extreme policies. (Though the Liberals depicted their permanent Coalition partner, the Nationals, as being part of a stable majority government.) For example, Turnbull argued that the Greens and Xenophon were opposing free trade and would add their weight to the pressure the Australian Council of Trade Unions (ACTU) was already placing on Labor to re-open free trade agreements (Turnbull 2016f). In Turnbull's view: 'it is another pointer to the chaos and economic uncertainty likely to arise if a Labor-GreensIndependents alliance is revived at this election' (ibid.). Turnbull contrasted such uncertainty with the 'stable Coalition majority government which 
I lead', emphasising that such stability was needed to tackle the economic and other challenges ahead (Turnbull 2016s). Meanwhile, Morrison put out an attack ad, 'The Greening of Labor', suggesting that Labor was being infiltrated and pressured by Greens into taking up ideologically extreme positions (Liberal Party of Australia 2016). Turnbull also moved to distance the Liberals from Pauline Hanson's One Nation. In line with his own small 'l' liberal position on social issues, Turnbull argued that 'Pauline Hanson is not a welcome presence on the Australian political scene-remember she was chucked out of the Liberal party' (SBS 2016).

By contrast, Shorten claimed that, despite such statements, Turnbull was actually under increasing pressure from the right in his party to embrace the type of 'extreme', socially divisive policies advocated by Pauline Hanson and that this pressure would become even greater in the aftermath of international developments such as the Brexit vote (Shorten 20160). Similarly, far from seeing Xenophon as being in the same camp as Labor, Shorten argued that Xenophon-team candidates could not be trusted to stand up for workers' penalty rates and actually had more in common with the Liberals on such issues (Shorten 2016n). Meanwhile, Deputy Leader of the Labor Party Tanya Plibersek mounted a sustained attack on the Greens, claiming that their extreme ideological rigidity undermined Labor's ability to bring in reforms (which often involved a long and incremental process). Furthermore, she argued that the Greens' strategy of trying to grow by targeting Labor voters rather than Coalition ones meant that the Greens saw Labor as their immediate enemy. Consequently, she claimed that the Greens' electoral strategy could end up assisting the conservative side of politics and preventing the election of a Labor government (Plibersek 2016). Shorten totally denied that Labor would be prepared to form either a 'coalition' or an 'alliance' with the Greens, emphasising the importance of voting for the certainty that would be provided by a Labor majority government (Shorten 2016m).

In other words, both major parties argued for the need to elect a majority government that, they claimed, would provide stability and policy certainty. Both suggested that their major party opponents would be hostage to ideologically extreme, minor party views. 


\section{Conclusion}

The narrowness of the Coalition's victory raises some questions about whether neoliberal economic policy is so easy to sell to the electorate these days, or whether Turnbull was partly facing the type of economic protest vote that Shorten had hoped to address with his more economically inclusive policies. ${ }^{8}$ It is also possible that Turnbull's relative reluctance to mobilise 'Culture War' issues, combined with his neoliberal economics, opened up opportunities for protest votes for extreme right parties, such as Pauline Hanson's One Nation, given their combination of Islamophobia and protectionism.

There were significant policy differences and perspectives between the major parties in the 2016 election, even if both claimed that only their opponents were ideological. Those ideological positions were reinforced via the evoking of emotion. Labor's 'Mediscare' campaign, for example, reinforced social democratic views on government providing good-quality public healthcare, while the Coalition's scare campaign that Labor was antibusiness and would ruin the economy reinforced their neoliberal ideology. Class and same-sex issues were also mobilised by both sides to make ideological points.

Somewhat unusually, Labor criticised Turnbull for being too ideological on economic policy and not ideological enough when it came to maintaining his small 'l' beliefs. Meanwhile, Turnbull criticised Labor for being ideologically antibusiness - a criticism that was potentially reinforced by (the historical aberration of) Labor's reluctance to spell out explicitly that many of its policies would benefit both labour and private enterprise. While Labor had firmly rejected a small-target strategy, was articulating a clearer ideological position than in some previous elections and had achieved a better result than many had anticipated, its primary vote remained relatively low (at 34.73 per cent, though up 1.35 per cent from the last election). Among other issues, Labor needs to reflect on whether its populist antibusiness rhetoric made it more difficult for it to counter the Coalition's claims that it was antibusiness and would therefore be a poor economic manager.

8 Paul Strangio (2016) has suggested that Turnbull is facing a historically changing policy cycle, moving towards support for a more activist state that is more compatible with Labor traditions than Liberal ones. 


\section{Acknowledgements}

My thanks for useful feedback from the editors and participants in the election workshop. This chapter draws on some material produced as part of an Australian Research Council-funded project (DP140100168) entitled, 'Expanding equality: A historical perspective on developments and dilemmas in contemporary Australian social democracy'.

\section{References}

Albanese, Anthony. 2016. 'Debate: Pyne v Albanese', Q\& $A, A B C$, 23 May. Available at: www.abc.net.au/tv/qanda/txt/s4445605.htm

Australian Labor Party (ALP). n.d.-a. 'Bill Shorten and Labor. We'll put people first'. Available at: www.billshorten.com.au

—. n.d.-b. 'Girls into code'. Available at: parlinfo.aph.gov.au/parlInfo/ search/display/display.w3p;query=Id\%3A\%22library\%2Fpartypol\%2 F $4563584 \% 22$

— n.d.-c. 'Growing together, Labor's agenda for tackling inequality'. Available at: www.alp.org.au/growing_together

_. n.d.-d. 'Marriage equality: Labor will legislate for marriage equality within the first 100 days of the next parliament'. Originally available at: www.100positivepolicies.org.au/marriage_equality (accessed 14 June 2016, site discontinued).

— n.d.-e. 'Save safe schools'. Originally available at: www.alp.org.au/ savesafeschools (accessed 14 June 2016, site discontinued).

— 2016. 'Bob Hawke speaks out for Medicare, do you?' YouTube, 11 June. Available at: www.youtube.com/watch?v=pZ9EfrpPcQs

Bowen, Chris. 2016a. 'Labor leads the way on structural reform'. Media release: 9 June. Available at: pandora.nla.gov.au/pan/78281/2016 0722-0938/www.chrisbowen.net/media-centre/media-releases 4535. html?newsId=7193 
—_. 2016b. 'What would Paul Keating argue about company tax?'. Media release: 7 June. Available at: pandora.nla.gov.au/ pan/78281/20160722-0938/www.chrisbowen.net/media-centre/ media-releasesa34d.html?newsId=7192

Crabb, Annabel. 2016. Stop at Nothing: The Life and Adventures of Malcolm Turnbull. Melbourne: Black Inc.

Dziedzic, Stephen and Jane Norman. 2016. 'Election 2016: Scott Morrison weighs in on gay marriage after Penny Wong comments'. $A B C$ News, 22 June. Available at: www.abc.net.au/news/2016-0622/election-scott-morrison-responds-to-penny-wong-same-sexmarriage/7532372

Hartcher, Peter. 2016. 'The great disappointment? Interview with Malcolm Turnbull'. Age, Insight, 11 June, 26.

Hudson, Phillip, 2016. 'Federal election 2016: Turnbull "arrogant" but voters like him'. Australian, 25 May. Available at: www.theaustralian. com.au/federal-election-2016/federal-election-2016-turnbullarrogant-but-voters-like-him/news-story/2b9545685a9d4cc7772759 ba661256fc

Johnson, Carol. 1986. 'Social harmony and Australian Labor: The Curtin and Chifley Governments' plans for Australian economic development'. Australian Journal of Politics and History 32(1): 39-51. doi.org/10.1111/j.1467-8497.1986.tb00339.x

1989. The Labor Legacy: Curtin, Chifley, Whitlam, Hawke. Sydney: Allen and Unwin.

—_. 2007. Governing Change: From Keating to Howard. 2nd edition. Perth: Network Books.

- 2011. 'Gillard, Rudd and Labor tradition'. Australian Journal of Politics and History 57(4): 562-79. doi.org/10.1111/j.14678497.2011.01614.x

Lewis, Rosie. 2016. 'Federal election 2016: Bernardi slams PM on Q\&A comment'. Australian, 22 June. Available at: www.theaustralian.com. $\mathrm{au} /$ federal-election-2016/federal-election-2016-bernardi-slams-pmon-qa-comment/news-story/bf2aab7b010b6f17d2a87ba2ea7ff81a 
Liberal Party of Australia. 2016. 'The Greening of Labor'. YouTube, 14 June. Available at: www.youtube.com/watch?v=eA4Me7X5Blw

Marr, David. 2016. Faction Man: Bill Shorten's Pursuit of Power. Melbourne: Black Inc.

Mayer, Sid. 2016. "'Unexcited" MPs worried they could be Gonski'. Australian, 21 April, p. 5.

Plibersek. Tanya. 2016. 'The McKell Institute: The progressive case for Labor'. Speech: 15 June. Available at: www.tanyaplibersek.com/ speech_the_mckell_institute_the_progressives_case_for_labor_ wednesday_15_june

Power, Shannon. 2016. 'LGBTI leaders urge Malcolm Turnbull to ditch plebiscite after Orlando shootings'. Star Observer, 14 June. Available at: www.starobserver.com.au/news/lgbti-leaders-urge-malcolm-turnbullto-ditch-plebiscite-after-orlando-shootings/150042

Shorten, Bill. 2016a. For the Common Good: Reflections on Australia's Future. Melbourne: Melbourne University Press.

— 2016b. 'Address to the Labor Caucus'. Labor Caucus Room, Parliament House, 23 February. Transcript. Available at: www. billshorten.com.au/address-to-the-labor-caucus

—. 2016c. 'Growing strong and fair: Labor's vision for the modern economy'. National Press Club, Canberra, 15 March. Transcript. Available at: www.billshorten.com.au/growing_strong_and_fair_ labor_s_vision_for_the_modern_economy

- 2016d. Interview with Leigh Sales. 7.30, ABC, 15 March. Available at: www.abc.net.au/7.30/content/2015/s4425667.htm

—. 2016e. 'Member's statements - Safe Schools Program'. House of Representatives, Canberra, 17 March. Transcript. Available at: www. billshorten.com.au/member_s_statements_safe_schools_program

- 2016f. Doorstop - Launceston, 8 May. Transcript. Available at: www.billshorten.com.au/doorstop_launceston_sunday_8_may_2016 
—_. 2016g. 'Address to the Reconciliation Australia Dinner Melbourne'. 27 May. Transcript. Available at: www.billshorten.com. au/address_to_the_reconciliation_australia_dinner_melbourne_ friday_27_may_2016

- 2016h. 'Leaders debate at the National Press Club'. Canberra, 29 May. Transcript. Available at: www.malcolmturnbull.com.au/ media/leaders-debate-at-the-national-press-club-canberra

__ 2016i. 'Only Labor will champion the march to gender equality'. 11 June. Available at: www.billshorten.com.au/only_labor_will_ champion_the_march_to_gender_equality

__ 2016j. Doorstop - Sydney, 11 June. Transcript. Available at: www. billshorten.com.au/doorstop_sydney_saturday_11_june_2016

—_. 2016k. 'Bill Shorten in Penrith'. $Q \& A, A B C, 13$ June. Available at: www.abc.net.au/tv/qanda/txt/s4454321.htm

—_. $2016 \mathrm{~m}$. Interview with Leigh Sales. 7.30, ABC, 23 June. Available at: www.abc.net.au/7.30/content/2016/s4488065.htm

—_. 2016n. Doorstop - Adelaide, 23 June. Transcript. Available at: www.billshorten.com.au/doorstop_adelaide_thursday_23_june_2016

__ 2016o. Doorstop - Townsville, 25 June. Transcript. Available at: www.billshorten.com.au/doorstop_townsville_saturday_25_june_ 2016

Shorten, Bill, Chris Bowen and Tony Burke. 2016. 'Transcript of Press Conference, Sydney', 10 June. Originally available at: www. billshorten.com.au/press_conference_sydney_friday_10_june_2016 (accessed 14 June 2016).

Special Broadcasting Service (SBS). 2016. 'Pauline Hanson not welcome presence says Turnbull'. SBS, 31 May. Available at: www.sbs.com. $\mathrm{au} /$ news/article/2016/05/31/pauline-hanson-not-welcome-presencesays-turnbull

Strangio, Paul. 2016. 'Balancing act: Correspondence'. Quarterly Essay 62: 89-91. 
Turnbull, Malcolm. 2009. 'PM's cheap money shot'. Australian, 7 March. Available at: www.theaustralian.com.au/archive/news/pms-cheapmoney-shot/story-e6frg73o-1111119056591

— 2016a. Doorstop - Robert Poate Centre, Canberra, 26 February. Transcript. Available at: pandora.nla.gov.au/pan/154649/201605080839/www.pm.gov.au/media/2016-02-26/doorstop-robert-poatecentre-canberra.html

2016b. Interview with Fran Kelly on RN Breakfast, $A B C$ Radio National Breakfast, 4 May. Transcript. Available at: pandora.nla.gov.au/ pan/154649/20160508-0839/www.pm.gov.au/media/2016-05-04/ interview-fran-kelly-rn-breakfast.html

- 2016c. Doorstop with Minister for Indigenous Affairs, 27 May. Transcript. Available at: www.malcolmturnbull.com.au/media/ doorstop-with-minister-for-indigenous-affairs

- 2016d. Doorstop at Engineers Australia, 6 June. Transcript. Available at: www.malcolmturnbull.com.au/media/doorstop-atengineers-australia

- 2016e. Interview with Leigh Sales. 7.30, $A B C, 8$ June. Transcript. Available at: www.malcolmturnbull.com.au/media/interview-withleigh-sales-7.30-abc

- 2016f. 'A stronger new economy to secure our future'. Speech: 10 June. Available at: www.liberal.org.au/latest-news/2016/06/10/ stronger-new-economy-secure-our-future

—. 2016g. Doorstop-Sunshine Coast, Qld, 11 June. Transcript. Available at: www.malcolmturnbull.com.au/media/doorstopsunshine-coast-qld

—. 2016h. 'Speech at Kirribilli House, Sydney',16 June. Transcript. Available at: www.liberal.org.au/latest-news/2016/06/16/speechkirribilli-house-sydney

- 2016i. 'Coalition to invest $\$ 15$ million protect older Australians'. Media release: 17 June. Available at: www.malcolmturnbull.com.au/ media/coalition-to-invest-15-million-protect-older-australians 
2016j. 'Online Leaders' Debate, Sydney', 17 June. Transcript. Available at: www.malcolmturnbull.com.au/media/online-leadersdebate-sydney

—_. 2016k. Joint doorstop-Alphadale, NSW, 17 June. Transcript. Available at: www.malcolmturnbull.com.au/media/joint-doorstopalphadale-nsw

—— 2016m. 'Securing South Australia's steel sector and jobs'. Media release: 19 June. Available at: www.malcolmturnbull.com.au/media/ securing-south-australias-steel-sector-and-jobs

__. 2016n. 'Prime Minister Malcolm Turnbull', $Q \mho A, A B C, 20$ June. Transcript. Available at: www.abc.net.au/tv/qanda/txt/s4463065.htm

—_. 2016o. Interview with Leigh Sales. 7.30, ABC, 24 June. Available at: www.abc.net.au/7.30/content/2016/s4488832.htm

__. 2016p. 'Speaking at a Community Lunch at the Glenelg Surf Life Saving Club, South Australia', 27 June. Transcript. Available at: www. malcolmturnbull.com.au/media/speaking-at-a-community-lunch-atthe-glenelg-surf-life-saving-club-south-au

__. 2016q. Interview with Alan Jones, 2GB, 29 June. Transcript. Available at: www.malcolmturnbull.com.au/media/interview-withalan-jones-2gb2

—. 2016r. 'Address to the National Press Club', 30 June. Transcript. Available at: www.malcolmturnbull.com.au/media/address-to-thenational-press-club

—. 2016s. Press Conference, Sydney, 1 July. Transcript. Available at: www.malcolmturnbull.com.au/media/press-conference-sydney

Turnbull, Malcolm and Julie Bishop. 2015. Press Conference, Parliament House, 14 September. Transcript. Available at: www.malcolmturnbull. com.au/media/transcript-vote-on-the-liberal-party-leadership

Turnbull, Malcolm, Barnaby Joyce and Fiona Nash. 2016. Joint doorstop - Alphadale, NSW, 17 June. Transcript. Available at: www.liberal.org. au/latest-news/2016/06/17/joint-doorstop-alphadale-nsw 
Wong, Penny. 2015. 'Why Labor Supports Trade - Australian Fabians Forum - Melbourne'. 13 June. Transcript. Available at: www. pennywong.com.au/speeches/why-labor-supports-trade-australianfabians-forum-melbourne/

— 2016a. 'Export Council of Australia - Australian Chamber of Commerce and Industry Trade Forum - Sydney'. 7 June. Transcript. Available at: www.pennywong.com.au/speeches/export-council-ofaustralia-australian-chamber-of-commerce-and-industry-trade-forumsydney/

—. 2016b. '28th Annual Lionel Murphy Memorial Lecture'. Canberra, 21 June. Transcript. Available at: www.pennywong.com. au/speeches/28th-annual-lionel-murphy-memorial-lecture-australiannational-university-canberra/

- 2016c. 'Interview: Penny Wong Shadow Trade Minister', Lateline, $A B C, 27$ June. Available at: www.abc.net.au/lateline/content/2016/ s4490117.htm 
This text is taken from Double Disillusion: The 2016 Australian Federal Election, edited by Anika Gauja, Peter Chen, Jennifer Curtin and Juliet Pietsch, published 2018 by ANU Press, The Australian

National University, Canberra, Australia.

doi.org/10.22459/DD.04.2018.03 